\title{
CORNALIS DE ALEMANIA, UN MINISTRIL DE JUAN II DE CASTILLA AL SERVICIO DE LA REALEZA PENINSULAR. ESTUDIO Y DOCUMENTOS (¿1426?-†1484)*
}

\author{
Francisco de Paula Cañas Gálvez \\ Universidad Complutense de Madrid**
}

\section{Resumen}

Cornalis de Alemania, ministril de chirimía de origen teutón, es paradigma de la trayectoria vital, curial y profesional de los músicos activos en el entorno de la realeza en el ocaso de la Edad Media. Formado presumiblemente en las prestigiosas escuelas de ministriles de la Europa del Norte, siendo muy joven recaló en la corte de Juan II de Castilla, por entonces uno de los centros políticos y culturales más activos y atractivos de la época, donde alcanzó un gran prestigio que le hizo viajar por algunas de las cortes más relevantes del momento. Al final de su vida sirivió a la reina Isabel la Católica y recaló en Valladolid, donde murió en 1484.

Palabras Clave: ministril, chirimía, Juan II de Castilla, Alfonso V de Aragón, Casa Real.

\section{MINISTRIL CORNALIS OF GERMANY, A LIFETIME OF SERVICE BETWEEN JUAN II OF CASTILE'S COURT AND OTHER PENINSULAR ROYAL HOUSEHOLDS. STUDY AND DOCUMENTS (¿1426?-†1484)}

\section{Abstract}

Cornalis of Germany, in his post as a ministrer of chalemie, can be regarded as the paradigm of the curial and professional trajectory of those active musicians working in the royal environment in the twilight of the Middle Ages. Presumably formed in prestigious North European schools of minstrels, he came to Juan II of Castile's court in his youth. There, at the time one of the most active and attractive political and cultural centers, Cornalis achieved great prestige, thus travelling through some of the most relevant courts of the moment. At the end of his life he worked for queen Isabella the Catholic and lived in Valladolid, where he died in 1484.

KeYwords: ministril, chalemie, Juan II of Castile, Alfonso V of Aragon, Royal Household. 
En les cases dels prínceps, segons que mostraantiquitat, juglars degudament poden ésser, cor lur offici dóna alegria, la qual los prínceps molt deuen desijar e ab honestat servar per tal que per aquella tristícia e ira foragiten e a totstemps se mostren pus gracioses ${ }^{1}$.

\section{INTRODUCCIÓN}

En este trabajo pretendo abordar la trayectoria biográfica y curial de Cornalis de Alemania, uno de los ministriles más activos y que más tiempo se mantuvo al servicio de las distintas cortes reales ibéricas del siglo xv. Su larga andadura palaciega, apuntada hace ya hace algunos años ${ }^{2}$, ejemplifica a la perfección, al menos en lo que la documentación conservada nos ha permitido comprobar, el perfil profesional de los músicos áulicos activos en el ocaso del Medievo. Formado presumiblemente en las prestigiosas escuelas de ministriles de Flandes y Alemania, a una edad temprana debió de recalar en la Península Ibérica, atraído, sin duda, por los brillos que en aquellos años ofrecían las cortes de los Trastámaras de Castilla, Aragón y Navarra ${ }^{3}$,

* Las siglas y abreviaturas utilizadas en este trabajo son las siguientes: ACA: Archivo de la Corona de Aragón. AGS: Archivo General de Simancas. CySR: Casa y Sitios Reales. RAH: Real Academia de la Historia.

** Agradezco al Dr. Stefano Maria Cingolani que me facilitara los documentos 1, 2 y 3 publicados en 5 . Apéndice documental. Forman parte de una colección de diplomas reales relativos a la actividad musical en las cortes ibéricas en el marco del proyecto The Last Song of the Troubadours: Linguistic Codification and Construction of a Literary Canon in the Crown of Aragon (14th-15th centuries), FP7 2009-2013-240170, dirigido por la Dr. Anna Aberni Jordà, de la Universidad de Barcelona.

1 «En los palacios de los príncipes, según la antigüedad lo muestra, debe de razón haber tañedores, por cuanto el oficio de ellos es dar placer y regocijar, lo cual deben mucho desear los príncipes y guardar con decoro, para que con ello echen de sí la tristeza y la ira y parezcan siempre afables», F.M. Gimeno, D. Gozalbo y J. Trenchs (eds.), Ordinaçions de la Casa y Cort de Pere el Cerimoniós. Valencia, Universidad de Valencia, 2009, cap. 28, p. 88.

2 F. de P. Cañas Gálvez, «La música en la Corte de Juan II de Castilla (1406-1454). Nuevas fuentes para su estudio». Revista de Musicología, vol. xxıII, núm. 2 (2000), pp. 380 y 393-394; «La música en la corte de Enrique IV de Castilla (1454-1474). Una aproximación institucional y prosopográfica». Revista de Musicología, vol. xxix, núm. 1 (2006), p. 269. M.C. González Marrero, La Casa de Isabel la Católica. Espacios domésticas y vida cotidiana. Ávila, Diputación Provincial de Ávila; Institución Gran Duque de Alba, 2004, p. 108, nota 316. T. KNIGHTON, «Instruments, Instrumental Music and Instrumentalists: Traditions and Transitions», en Companion to Music in the Age of the Catholic Monarchs, Boston, Leiden: Brill, 2017, pp. 97-144. Recientemente también lo ha hecho F. Villanueva Serrano, A la onor e mostrar stado. La música en la corte de Juan II de Aragón. Madrid, Sociedad Española de Musicología, 2017, p. 214.

${ }^{3}$ La bibliografía acerca de los aspectos curiales y de mecenazgo artístico de los Trastámaras es amplísima. A modo de visión de conjunto y con una amplia bibliografía final citamos los trabajos de J. Valdeón Baruque, Los Trastámara: el triunfo de una dinastía bastarda. Madrid, Temas de Hoy, 2001 y de este mismo autor, La dinastía de los Trastámara. Madrid, Ediciones El Viso, 2006. Algunas cuestiones de carácter general en lo relativo a la música en los mencionados trabajos de F. de P. Cañas Gálvez, «La música en la Corte de Juan II...», pp. 367-394, «La música en la corte de Enrique IV...», pp. 217-313 y «Música, poder y Monarquía en la Castilla Trastámara (1369-1474). 
de larga tradición en el patronato, mecenazgo y demanda de toda suerte de artistas, pero en especial de juglares, ministriles y cantores, del mayor prestigio internacional ${ }^{4}$.

La reconstrucción biográfica de un músico de este periodo está sumida en numerosas dificultades, algunas de ellas insalvables. Esta circunstancia, extensible a la mayor parte de los miembros del entorno cortesano de los monarcas y príncipes de la etapa bajomedieval castellana, reside, como es bien sabido, en la no excesiva abundancia de fuentes documentales de carácter administrativo que nos han llegado de este reino; la ausencia de libros de cédulas, mayordomos, camareros, tesoreros y registros de cancillería, muy escasos hasta el reinado de los Reyes Católicos, dificultan enormemente el rastreo de estos personajes, aunque en el caso que ahora nos ocupa la existencia de varios documentos de carácter personal ayudan de forma excepcional a perfilar con cierta precisión el contexto, no sólo curial, sino también social, en el que nuestro protagonista encajó su trayectoria vital.

Un apéndice final con un total de ocho documentos procedentes de los archivos de Simancas y Corona de Aragón completan este estudio5.

Nuevas perspectivas de análisis». Revista de Musicología, vol. xxxıI, núm. 1 (2009), pp. 359-378. El papel de la música en el organigrama de la Casa Real castellana bajomedieval también en F. DE P. Cañas Gálvez, «La Casa de Juan I de Castilla: aspectos domésticos y ámbitos privados de la realeza castellana a finales del siglo XIV (ca. 1370-1390)». En la España Medieval, vol. 34 (2011), pp. 158-161; «La Casa del infante Fernando de Castilla: corte, poder y representación político-institucional en el ocaso del Medievo (1385-1408)». Boletín de la RealAcademia de la Historia, tomo cCxxiII, cuaderno I, pp. 61-70 y «La cámara de Juan II: vida privada, ceremonia y lujo en la corte de Castilla a mediados del siglo Xv», en Evolución y estructura de la Casa Real de Castilla, vol. 1, Madrid, Ediciones Polifemo, 2010, pp. 152-153. Para el caso aragonés remitimos a la obra de M.C. Gómez Muntané, La música en la Casa Real catalano-aragonesa, 1336-1442, vol. 1, Barcelona, Antoni Bosch, editor, 1977 y los trabajos más recientes de T. Knighton, Música y músicos en la corte de Fernando el Católico, 14741516. Zaragoza, Institución Fernando el Católico, 2002. Para el ambiente musical en el periodo bajomedieval en Navarra remitimos a los estudios de H. Anglés, Historia de la música medieval en Navarra. Pamplona, Diputación Foral de Navarra, 1970 y M. Narbona Cárceles, «La actividad musical en la corte de Carlos III el Noble de Navarra, 1387-1425». Principe de Viana, Año 67, núm. 238 (2006), pp. 313-334. Una visión de conjunto se puede ver en M.C. Gómez Muntané, La música medieval en España. Edition Reichenberger, Kassel, 2001.

${ }^{4}$ M. Gómez Muntané, «Sobre el papel de España en la música europea del siglo xiv y primer tercio del siglo XV», en J. López-Calo, I. Fernández de la Cuesta y E. Casares Rodicio (coords.), España en la música de occidente: actas del congreso internacional celebrado en Salamanca, 29 de octubre-5 de noviembre de 1985, vol. 1, 1987, pp. 45-48. F. DE P. Cañas Gálvez, «Música, poder y Monarquía...».

${ }^{5}$ Los fondos del Archivo de la Corona de Aragón, con series completas de libros de cancillería y tesorería, son esenciales para reconstruir la actividad musical no sólo en Aragón, sino también en el resto de reinos hispánicos del periodo bajomedieval. Una visión de conjunto de todas estas series en F. Udina Martorell, Guía histórica y descriptiva del Archivo de la Corona de Aragón. Madrid, Dirección General de Bellas Artes y Archivos, 1986. 


\section{LOS PRIMEROS AÑOS: DE ALEMANIA A LA CORTE DE CASTILLA}

No sabemos nada de los primeros años de Cornalis de Alemania. Su nombre evidencia su origen germano, por lo que es fácil suponer que se formara en alguna de las elitistas escuelas de ministriles de Francia, Flandes o Alemania ${ }^{6}$, por entonces en pleno apogeo, junto a las italianas ${ }^{7}$, dentro del contexto general de esplendor político, económico, social y cultural que disfrutaban ambos espacios y el desarrollo excepcional de la escuela franco-flamenca, que, impulsada por el mecenazgo de los duques de Borgońa, pronto extendería su influencia por toda Europa occidental ${ }^{8}$.

Una vez finalizada una primera formación ${ }^{9}$, Cornalis debió de entrar a formar parte de lo que Gómez Muntané ha definido como «mercado internacional de ministriles», en el que, en opinión de esta misma autora, «la ley de la oferta y la

${ }^{6}$ Muy activas ya a mediados del siglo xiv. Los ejemplos de juglares y ministriles enviados desde la Península Ibérica allí son numerosos. Citar, como testimonio, los de Guillot Vaguer, juglar de cornamusa de Pedro IV de Aragón, en enero de 1352 marchó a Alemania «... a les escoles de música», o el de Tomasí de Chaumont, ministril de Pedro IV, estudiando entonces en estas mismas escuelas en enero de 1372 y para quien Pedro IV de Aragón dispuso que le fueran dadas todas las ayudas posibles. En marzo de 1386 Jacquect de Troyes, Gautier de la rota, Hennequí, Pifet y Enric se trasladaron a Francia y Alemania para estudiar en las citadas escuelas musicales. 1352, enero, 30. Barcelona. ACA, Real Patrimonio, Maestre Racional, Reg. 869, f. 138r., 1372, enero, 16. Barcelona. ACA, Cancillería, Reg. 1.735, f. 68r-v. (Publicado este último por M.C. Gómez Muntané, La música en la Casa Real..., vol. 1, Doc. 14, p. 133) y 1386, marzo, 28. Zaragoza. ACA, Cancillería, Reg. 1.673, f. 90r, respectivamente.

7 M.C. Gómez Muntané, La música en la Casa Real..., vol. 1, pp. 73-77, «Minstrel schools in the late Middle Ages». Early Music, vol. XviII (1990), pp. 212-216, y «Las escuelas de ministriles a finales de la Edad Media». Goldberg, núm. 41 (2006), pp. 59-67.

${ }^{8}$ Para la música en la corte borgońona del siglo xv es de referencia el estudio clásico de J. Marix, Histoire de la musique et des musiciens de la cour de Bourgogne sous le règne de Philippe le Bon (1420-1467). Estrasburgo, Hetiz \& Co, 1939. También, C.M. Wright, Music at the Court of Burgundy, 1364-1419. A Documentary History. Musicological Studies, xxviII, Henryville, PA, Institute of Mediaeval Music, 1979; W. Paravicini, «The Court of the Dukes of Burgundy. A Model for Europe?», en R.G. Asch y A.M. Birke (eds.), Princes, Patronage, and the Nobility. The Court at the Beginning of the Modern Age. c. 1450-1650, Oxford, Oxford University Press for the German Historical Institute Londres, 1991, pp. 69-102; D. Fiala, Le mécénat musical des ducs de Bourgogne et des princes de la Maison de Habsbourg (1467-1506). Étude documentaire et prosopographique. Tesis Doctoral inédita, Université François Rabelais, Tours, 2002 y A. Fernández de Córdova Miralles, "L'impact de la Bourgogne sur la cour castillane des Trastamare», en W. PARAVICINI (dir.), La cour de Bourgogne et l'Europe. Le rayonnement et les limites d'un modèle culturel, Ostfildern, Jan Thorbecke Verlag, 2013, pp. 593-630. El reciente coloquio Jeanne d'Arc en Histoire et en Musique organizado por el Consejo Departamental de Vosges, la Universidad de Lorena y el CRULH el 25 de abril de 2015 bajo la dirección Catherine Guyton y Nadège Taureau ofreció una revisión general de los contextos musicales, políticos y sociales del panorama musical en Francia y Flandes en el contexto de las tres primeras décadas del siglo $\mathrm{xv}$.

9 Parece que los viajes de los ministriles y cantores a estas escuelas eran frecuentes para mantenerse así a la vanguardia en interpretación y repertorios. En febrero de 1377, por ejemplo, Esteve Ravina y Henri Crespin, ministriles de Pedro IV de Aragón, recibieron del tesorero real Pere Desvall 100 florines de oro para ir a Alemania "per aprendre noves músiques». 1377, febrero, 7. Barcelona. ACA, Cancillería, Reg. 1.360, f. 166r. 
demanda estaba regulada de forma básica por la calidad de la mercancía, en este caso del músico» ${ }^{10}$.

En el caso de Castilla la asistencia de instrumentistas y cantores extranjeros fue frecuente desde al menos el siglo XIV ${ }^{11}$, siendo los flamencos y particularmente los alemanes, sin duda alentados por las estrechas relaciones artísticas que la Corona mantenía con aquellos espacios geográficos ${ }^{12}$, los que contaron con una presencia continuada desde aquellas fechas hasta tiempos de Enrique $\mathrm{IV}^{13}$, como así ponen de manifiesto los casos, entre otros muchos, de Johan de Alemania, trompeta, juglar y ministril de Juan I de Castilla (1380) ${ }^{14}$; Joan Monge, ministril alemán enviado por Martín I a la corte de Enrique III de Castilla $(1405)^{15}$; Albert de Alemania, ministril de Juan II de Castilla en Zaragoza con motivo de la coronación de Fernando I como rey de Aragón (1414) ${ }^{16}$; el anónimo cantor alemán que Alfonso $\mathrm{V}$ de Aragón tenía previsto enviar a su primo Juan II y que finalmente no pudo ir por haber enloquecido $(1420)^{17}$; Juan de Colonia, también ministril de chirimia como Cornalis, (1426) ${ }^{18}$; Johanes de Alemania, «tañedor de los huérganos» de la cámara de Juan II $(1454)^{19}$; o Enrique de Colonia, «maestro de fazer órganos» para la corte de Enrique IV $(1459)^{20}$.

${ }^{10}$ M.C. Gómez Muntané, La música en la Casa Real..., vol. 1, p. 63.

11 F. de P. Cañas Gálvez, «La Casa de Juan I de Castilla...», pp. 158-161.

${ }_{12}$ Sabemos que en 1438 Juan II de Castilla había enviado a Flandes a Juan de Morillo con la intención de adquirir allí las mejores piezas artísticas destinadas a la corte castellana y posiblemente también con la de contratar a los ministriles y cantores más sobresalientes. F. de P. CAÑAs Gálvez, "Juan II de Castilla y el tríptico de Miraflores: marco espiritual, proyección política y propaganda regia en torno a una donación real (1445)», en L. Campbell y J.J. Pérez Preciado (eds.), Rogier van der Weyden y España. Actas del Congreso Internacional, Madrid, Museo del Prado, 2016, pp. 20-29.

${ }_{13}$ H. ANGLÉs, "Cantors und Ministrers in den Diensten der Könige von Katalonien-Aragonien im 14. Jahrhundert». Berich über den Musikwinssenschaftlichen Kongress in Basel 1924, Leipzig, 1925, pp. 55-66; "El músci Jacomí al servei de Joan I i Martí I durante els anus 1372-1404», en Homenatge a Antoni Rubió i Lluch, Barcelona, 1935, pp. 613-625; y «Els cantors i organistes franco-flamencs i alemanys a Catalunya els segles XIV-XVI». Scripta Musicologica, cura et studio Iosephi López Calo, II, Roma, 1975, pp. 735-751.

${ }_{14}$ En 1380, Johan de Alemania era ya un músico de prestigio y larga trayectoria. En marzo de 1341 sabemos que servía a Johan de Xallo y entre enero y febrero de 1351 era juglar y trompeta del duque Enrique de Sajonia. Según Andrés Descalzo Pedro IV utilizó sus servicios de manera eventual. A. Descalzo, «Músicos en la corte de Pedro IV el Ceremonioso (1336-1387)». Revista de Musicología, vol. XIII, núm. 1 (1990), p. 88.

${ }_{15}$ ACA, Cancillería, Reg. 2.179, ff. 230v-231r.

${ }_{16}$ ACA, Cancillería, Reg. 2.413, f. 16r.

17 «es lunático, car cierto tiempo es stado que no havia ceso, et es tal que buenament no puede partir de ciertos companyones de su nación». 1420, febrero, 20. Tortosa. ACA, Cancillería, Reg. 2.671, fol. 21r-v. M.C. Gómez Muntané, La música en la Casa Real..., vol. I, Doc. 269, p. 213.

${ }_{18}$ ACA, Reg. 2.576, f. 152r. y Reg. Reg. 2.681, f. 75.

19 F. de P. Cañas Gálvez, «La música en la corte de Juan II...», p. 382 y «El despensero mayor de las raciones de la Casa del rey. Estudio institucional y documentos de un oficio curial en la Castilla Trastámara (1380-1465)». Cuadernos de Historia del Derecho, vol. 22 (2015), p. 149 y Doc. 34, p. 178.

${ }^{20}$ F. de P. Cañas Gálvez, «La música en la corte de Enrique IV...», pp. 240-246 y 273. 
Y lo mismo podríamos decir de la corte portuguesa, donde Juan I contaba ya en 1427 con un conjunto de al menos de tres ministriles de chirimía, todos ellos alemanes como luego veremos ${ }^{21}$, y también de la aragonesa ${ }^{22}$ y la navarra ${ }^{23}$.

No sabemos con precisión cuándo recaló Cornalis en tierras hispanas. Si como asegura Villanueva Serrano nuestro ministril a lo largo de su vida apareció citado en la documentación como "Corneli», "Cornalis», "Cornelius», "Cornello», «Cornella», «Corniels», "Cornilla», «ंClaus?» y «iElaus? de Alemania», «Alemanya», o «de la aya $»^{24}$, es muy probable que el Claus que en noviembre de 1426 aparecía como ministril de chirimía de Juan II de Castilla, la primera vez que se le cita asociado a este instrumento ${ }^{25}$, en la corte de Alfonso V de Aragón, fuese el mismo músico al que estamos dedicando estas páginas. Su estancia valenciana, en la que estuvo acompańado de Castilla, rey de Armas de Juan II de Castilla; Jean Colleville; Perrinet y Jaquet (o Jacquinot), también ministriles de chirimía del rey castellano, se cerraba en noviembre de ese año con la extensión por parte de Alfonso V del correspondiente salvoconducto para volver con sus compañeros a Castill ${ }^{26}$ y la entrega por parte del tesorero real Francisco Zarzuela de 300 florines para que pudieran materializar el viaje ${ }^{27}$.

La documentación del Archivo de la Corona de Aragón nos permite conocer, como acabamos de comprobar, el nombre de los ministriles de chirimía del rey de Castilla en una fecha tan temprana como 1426 y nos ofrece detalles muy sustanciosos sobre el número de sus integrantes y su dimensión representativa y heráldica desempeñada en el marco de embajadas y otras misiones de carácter principalmente diplomático, de ahí que en ocasiones fueran acompañados de un rey de armas, como sucedió en 1426 con Castilla ${ }^{28}$.

${ }^{21}$ ACA, Cancillería, Reg. 2.789, f. 29v.

22 M.C. Gómez Muntané, La música en la Casa Real..., vol. 1, pp. 25-47.

${ }^{23}$ H. Anglés, Historia..., pp. 377-391. Una bibliografía ampliada sobre estos aspectos relativos a Aragón y Navarra en M. C. Gómez Muntané, La música medieval..., pp. 277-278.

${ }^{24}$ F. Villanueva Serrano, A la onor..., 214.

25 «Instrumento de boca a modo de trompeta derecha, sin buelta, de ciertas maderas fuertes, pero que se labran sin que tengan repelos». S. DE Covar rubias, Tesoro de la lengua castellana o española. Madrid, Luis Sánchez, 1611, p. 294r-v. Más detalles en R. Andrés, Diccionario de instrumentos musicales. Desde la Antigüedad hasta J.S. Bach. Barcelona, Península, 2001, pp. 77-80.

26 1426, noviembre, 8. Valencia. ACA, Cancillería, Reg. 2.576, f. 152r. Véase 5. ApÉNDice Documental. Doc. 1.

27 1426, noviembre, 10. Valencia. ACA, Cancillería, Reg. 2.681, f. 75. Véase ApÉndice DOCUMENTAL. Doc. 2.

${ }^{28}$ En octubre de 1431 León era rey de armas, mientras que Vencedor aparecía como heraldo y Restre y Pastengla como persevantes de Juan II de Castilla. A su paso por tierras aragonesas Alfonso V les concedió licencia para pasar por Cataluña camino de Francia (1431, octubre, 9. Barcelona). Por su parte, en 1453 eran dos los Reyes de Armas al servicio de Juan II de Castilla: Toledo y Castilla. El primero recibía por el desempeño de su oficio un total de 2400 maravedís correspondientes al tercio segundo de su quitación de ese año de 1453. Castilla, por su parte, era obsequiado por el monarca en julio de ese mismo año con «vn jubón de damasco pardillo, de los quel rey señor dexa». En 1444 Vizcaya era faraute de Juan II y en 1456 Sevilla era rey de armas de Enrique IV. Tanto ministriles como Reyes 
El siguiente cuadro evidencia que estos conjuntos instrumentales estuvieron integrados por un número variable de miembros, desde los cuatro a seis chirimías en Aragón entre los años 1418 y 1433, a los que habría que añadir un trompeta (Joan Monsenyor en 1418-1420 y Arnau Marxant en 1433), a los cinco que conformaban la cobla de Juan II de Castilla en 1426 y los cuatro en 1454 hasta los tres al servicio de Juan I de Portugal en 1426, número, este último, que durante las décadas de 1460 a 1480 , se terminaría imponiendo en buena parte de las cortes peninsulares ${ }^{29}$.

\begin{tabular}{|c|c|c|}
\hline Monarca & MinisTRILES DE CHIRIMÍA & FECHAS \\
\hline \multirow{13}{*}{ Alfonso V de Aragón } & Aliot Nicola & IX-1418 - III-14201 \\
\hline & Jean Colleville & “ \\
\hline & Perrinet Renó & “ \\
\hline & Jean Verdet & “ \\
\hline & Jean de Massý & XII-1418 - III- $1420^{2}$ \\
\hline & Cosí de Cella & “ \\
\hline & & \\
\hline & Jean Boisart (Verdolet) & $V-1432^{3}$ \\
\hline & Jean Bolite & “ \\
\hline & Jean Gany & “ \\
\hline & Arnau Marxant & $V-1432-V-1433^{4}$ \\
\hline & Colin Boisart & \\
\hline & Jean Boisart & \\
\hline
\end{tabular}

de Armas, farautes y persevantes estaban exentos del pago de aduanas y tributos de todas las «ropas e joyas e otras sus cosas que metieren a los sus regnos». ACA, Cancillería, Reg. 2.582, f. 117v. RAH, Salazar, 9/808. ACA, Cancillería, Reg. 1.934, f. 123r. F. de P. Cañas Gálvez, «El despensero...», pp. 147 y Doc. 23, p. 172. F. de P. Cañas Gálvez, La cámara real de Juan II de Castilla. Cargos, descargos, cuentas e inventarios (1428-1454). Madrid, Ediciones de La Ergástula, 2016, pp. 115-116. Sobre el papel institucional y representativo de los Reyes de Armas en tiempos de Juan II véase F. de P. Cañas Gálvez, «La cámara de Juan II...», pp. 122-124, 148 y 186.

${ }^{29}$ F. de P. Cañas Gálvez, «La música en la corte de Enrique IV...», pp. 235-236. 


\begin{tabular}{|c|c|c|}
\hline \multirow{9}{*}{ Juan II de Castilla } & Claus & XI-1426 \\
\hline & \multicolumn{2}{|l|}{ Juan de Colonia } \\
\hline & Jean Colleville & “ \\
\hline & Jacquinot & “ \\
\hline & Perrinet & “ \\
\hline & Cornalis de Alemania & $1454^{6}$ \\
\hline & Martín Muñoz del Cardoso & “ \\
\hline & Sancho Barquero & “ \\
\hline & Pedro de Fox ${ }^{7}$ & “ \\
\hline \multirow{3}{*}{ Juan I de Portugal } & Pere Savall (¿Paravar, Perceval?) & II-III-1427 \\
\hline & Lleonard & “ \\
\hline & Enrique & “ \\
\hline \multicolumn{3}{|c|}{ 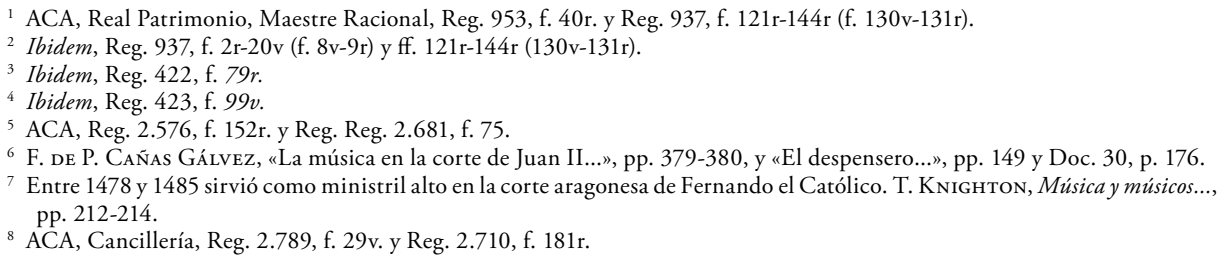 } \\
\hline
\end{tabular}

\section{CONSAGRACIÓN: NÁPOLES, CASTILLA, ARAGÓN Y PORTUGAL (1444-1484)}

Las lagunas documentales conocidas silencian el nombre de Cornalis de Alemania, en sus múltiples variantes, desde noviembre de 1426 hasta marzo de 1444.

Según apuntábamos más arriba, su papel como ministril de un instrumento alto debió de ser relevante en las escenificaciones desplegadas por la monarquía durante aquellos años, y así, a las ya mencionadas misiones diplomáticas, habría que añadir su más que posible participación en la proclamación de paces, treguas y acuerdos, campañas militares, recepciones y entradas en villas y ciudades, nacimientos, banquetes y bailes en la corte.

Es muy probable por ello que Cornalis fuera uno de los ministriles que tocaron en las casas del condestable Álvaro de Luna en Madrid con motivo del nacimiento de su hijo en junio de 1435. La Crónica del Halconero asegura que en las fiestas que se siguieron al bautizo «tocaron los ministriles, e dançó el Rey e la Reyna, con ciertos gentiles onbres, que podían ser fasta diez, cada vno con su dama ${ }^{30}$.

30 P. Carrillo de Huete, Crónica del halconero de Juan II. Edición y estudio por Juan de Mata Carriazo, Madrid, Espasa-Calpe, 1946, capítulo clxxxıv, p. 211. Sobre el papel de ministriles, 
Las fuentes coetáneas señalan que los ministriles, en especial los de instrumentos de viento, tañían ante el rey en las comidas públicas. Las Ordinaçions de Pedro IV de Aragón son muy claras en este sentido cuando afirman que «'offici dels quals s'esguart que totstemps Nós, públicament menjants" "31, salvo "en la Quaresmane en dia de divenres, si donchs gran festa no era, que.ls dits trompadores, trompeta e tabaler lur offici facen en lo comensament de la taula ne en la fin $»^{32}$, información que queda contrastada en Castilla con las noticias que nos aporta la Crónica del Condestable cuando al narrar el banquete que Álvaro de Luna ofreció en su alcázar de Escalona en diciembre de 1448 a los reyes de Castilla asegura que los distintos platos del menú fueron servidos por los maestresalas con «grandes e nuevas çirimonias [...] levando ante sí muchos minestriles, e tronpetas, e tanborinos $»^{33}$.

Fue en el marco de estos despliegues cortesanos como Cornalis consiguió fraguar su fama de músico excelente dentro y fuera de las fronteras castellanas. Su prestigio entonces debía de ser tal que en marzo de 1444, todavía al servicio de Juan II de Castilla, fue llamado junto a otros tres ministriles más de este monarca (Sacotey de Barcelona, Gilet y Arnau) por Alfonso V de Aragón para formar parte de los músicos que integraban su esplendorosa capilla musical y su corte napolitana de letrados y humanistas ${ }^{34}$.

Los datos y cifras manejados evidencian el interés del Magnánimo por hacerse con sus servicios: trato de privilegio para él, sus compañeros y esposas a su llegada a Barcelona, donde se les adelanterían 200 florines de oro del primer año,

trompetas y chirimías en este tipo de acontecimientos en la Castilla del siglo xv remitimos al trabajo de M.C. Gómez Muntané, «La música laica en el reino de Castilla en tiempos del Condestable Don Miguel Lucas de Iranzo (1458-1473)». Revista de Musicología, vol. xIX, núms. 1-2 (1986), pp. 25-45.

31 Ordinaçions..., p. 88: «... el oficio de los cuales sea tañer juntamente con el principio y fin de la comida, las veces que comiéramos en público...».

32 Ordinaçions..., p. 88: «... en tiempo de Cuaresma ni en día viernes toquen los dichos ministriles, atabalero y trompeta que en principio y fin de la comida, si ya no fuese fiesta muy solemne».

${ }_{33}$ G. Chacón, Crónica de Don Álvaro de Luna, condestable de Castilla, maestre de Santiago. Edición y estudio por J. de Mata Carriazo, Madrid, Espasa-Calpe, 1940, cap. LXXIV, p. 220.

${ }_{34}$ La documentación le menciona entonces como Elaus o Claus de Alemania lo que ha llevado a algunos investigadores a pensar de que quizá pudiera tratarse de algún familiar. H. ANGLÈs, La música..., p. 22. F. Villanueva Serrano, A la onor..., p. 214. Acerca de la música en la corte napolitana del Magnánimo, véase H. AngLÉs, «La música en la corte real de Aragón y de Nápoles durante el reinado de Alfonso V el Magnánimo (1416-1458)». Cuadernos de Trabajos de la Escuela Española de Historia y Arqueología en Roma, vol. 11 (1961), pp. 83-141; A. Atras, Music at the Aragonese Court of Naples. Cambridge, Cambridge University Press, 1995; G. D’Agostino, «La musica, la cappelle e il cerimoniale alla corte aragonese di Napoli'", en Cappelle musicali fra corte, stato e chiesa nell'Italia del rinascimento. Atti del convegno internazionale Camaiore, 21-23 ottobre 2005, Florencia, Olschki, 2007, pp. 153-180; M.C. Gómez Muntané, «La música en la corte de Alfonso V el Magnánimo», en $A$ la buisqueda del Toisón de Oro: la Europa de los príncipes, la Europa de las ciudades: Almudín, Museo de la Ciudad, 23 de marzo al 30 de junio de 2007, Valencia, Generalitat Valenciana, 2007, vol. 1, pp. 201-211 y "Música y corte a fines del Medioevo: el episodio del Sur», en Historia de la música en España e Hispanoamérica, vol. 1 (De los orígenes hasta c. 1470), Madrid, Fondo de Cultura Económica, 2009, pp. 238-320. 
además de un sueldo de 400 florines de oro de Aragón anuales con carácter vitalicio para cada uno de ellos ${ }^{35}$.

No sabemos con detalle cuándo volvió Cornalis a Castilla, pero en octubre de 1447 todavía permanecía en tierras italianas. La documentación conservada en Simancas evidencia que en abril de 1454 se hallaba de nuevo en la corte de Juan II. Por entonces, y como apuntábamos más arriba, formaba parte de un conjunto de chirimías integrado por cuatro individuos, dos de ellos al parecer castellanos (Martín Muñoz del Cardoso y Sancho Barquero), otro probablemente francés (Pedro de Fox) y el propio Cornalis, alemán.

Su ración anual de 6000 maravedíes, idéntica a la de sus tres compañeros, se le pagaba en tres tercios de 2000 maravedíes $^{36}$. Se trataba de una cantidad baja en comparación con la percibida por otros servidores reales de tipo medio, cuyas cantidades anuales por este mismo concepto oscilaban entre los 18000 del platero Diego de León y los 12000 de algunos guardas y el minador Tomás Bretón ${ }^{37}$, pero en todo caso en consonancia con la recibida por otros músicos al servicio de Juan II en aquellas mismas fechas como podemos comprobar en la siguiente tabla ${ }^{38}$ :

\begin{tabular}{llcc}
\multicolumn{1}{c}{ Nombre } & \multicolumn{1}{c}{ Oficio } & Fecha & RACiONes $^{1}$ \\
\hline $\begin{array}{l}\text { Álvaro Fernández } \\
\text { Juan de Castro }\end{array}$ & Organistas & 1453 & 6460 \\
\hline Álvaro Fernández & Organista & 1453 & 3000 \\
\hline & & 1453 & 3420 \\
Guillemýn Menasir & Tenor de la capilla & 1453 & $798^{2}$ \\
& & 1453 & 3400 \\
\hline Juan Martínez de Villarreal & Capellán y cantor & 1454 & 3000 \\
\hline Fernando de Sevilla & Cantor & 1453 & 3000 \\
\hline \multirow{2}{*}{ Guyllén de Inglaterra } & Tañedor de arpa & 1453 & 3000 \\
\hline Iohanes de Alemania & Tañedor de los órganos de la cámara & 1454 & 1500 \\
\hline
\end{tabular}

${ }^{1}$ Las sumas van indicadas en maravedíes.

2 Cantidad adeudada de su ración de 1453.

${ }^{35}$ H. Anglés, La música en la Corte de los Reyes Católicos. I. Polifonía religiosa. Barcelona, CSIC, 1960, pp. 18-25. M.C. Gómez Muntané, La música en la Casa Real..., vol. 1, pp. 104-112. Véase 5. Apéndice Documental. Doc. 3.

${ }^{36}$ F. De P. Cañas Gálvez, «La música en la corte de Juan II...», p. 380 y «El despensero...», p. 149. Véase 5. Apéndice Documental. Doc. 4.

37 F. de P. Cañas Gálvez, «El despensero...», p. 149.

38 Ibidem, pp. 146-150. 
Tras pasar algunos años en Castilla, Cornalis inició un incesante periplo dentro y probablemente fuera de la península. Villanueva Serrano habla de la posibilidad de un nuevo viaje a Nápoles acompañando al príncipe de Viena, pues entre los meses de septiembre y octubre de 1461 figuró en una lista de perceptores de gajes de la Casa de don Carlos y a partir de esa última fecha, ya fallecido el de Viana, parece que por voluntad de Juan II de Aragón pasó a formar parte de los servidores del príncipe Fernando ${ }^{39}$. En 1462 todavía seguía en tierras aragonesas intengrando un conjunto musical compuesto por Sancho Vaguer, probablemente el mismo Sancho Barquero (o Vaquero) con el que aparecía en Castilla en 1454, y Arnault de Gar$b_{i e}{ }^{40}$. Tres años más tarde, en octubre de 1465 , estaba de nuevo en Castilla, junto a Juanín y Valemy como ministril alto de Alfonso V de Portugal, siendo recibido por Enrique IV, que le obsequió con ricas telas entre las que se mencionan «ocho varas de Ruán mayor leonado e tres varas de seda ${ }^{41}$. Años más tarde, en junio de 1478, figuraba como tañedor de sacabuche y chirimía junto a Fernán Desbardada, Sancho Vaquero, su antiguo compañero, Arnao y Beltrán ${ }^{42}$.

Todo parece señalar que a finales de aquella década o en los comienzos de la siguiente, se asentó definitivamente en la corte castellana fijando su residencia en Valladolid, villa cortesana por excelencia y en la que residían algunos de los artesanos, oficiales e instituciones más relevantes de la Corona, y de la que, además, era originaria su esposa Catalina Pérez ${ }^{43}$.

\section{3. ÚLTIMOS AÑOS. MUERTE Y HEREDEROS}

Cornalis pasó sus últimos años de vida al servicio de la reina Isabel la Católica. En 1480 figuraba entre los miembros de su Casa como «ministril alto» con una quitación anual de 30000 maravedíes que se le siguieron librando hasta 1484, año en el que falleció «antes de cunplido el año».

El 29 de junio de ese año, sintiendo ya próxima la muerte, había firmado en la villa del Esgueva, ante Juan Álvarez de Valladolid ${ }^{44}$, una carta por la que concedía

39 F. Villanueva Serrano, A la onor..., p. 214.

40 T. Knighton, Música y músicos..., p. 148, citado por F. de P. Cañas Gálvez, «La música en la corte de Enrique IV...", p. 269.

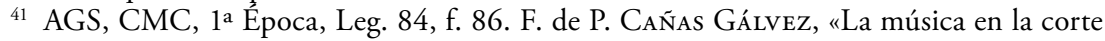
de Enrique IV...», p. 269 y Doc. 24, pp. 306-307.

${ }^{42}$ F. de P. Cañas Gálvez, «La música en la corte de Enrique IV...», p. 269.

${ }^{43}$ Sobre el papel de Valladolid como centro de poder en la Castilla del siglo xv, véase A. Rucquor, Valladolid en la Edad Media, vol. 2, Valladolid, Junta de Castilla y León, 1997, pp. 21-107; F. de P. Cañas Gálvez, «La itinerancia de la corte de Castilla durante la primera mitad del siglo Xv: el eje Burgos-Toledo, escenario burocrático-administrativo y político de la Monarquía en tiempos de Juan II", en L'Itinérance des cours (fin $X I I^{\mathrm{e}}$. siècle milieu $X V^{\mathrm{e}}$. siècle): un modèle ibérique?, e-Spania, núm. 8 (2009). (En línea).

44 «Escrivano de cámara del rey e reyna, nuestros señores, e su notario público en la su corte e en todos los sus reynos e seńoríos e escrivano de la su abdiençia e de la provinçia de Castilla 
poder a su mujer, Catalina Pérez, para que en su nombre pudiera otorgar testamento, circunstancia un tanto particular teniendo en cuenta que el propio Cornalis se declaraba en ese momento «sano de mi cuerpo e en mi seso e entendimiento natural, tal qual nuestro señor Dios plogó de me dar», anulando a su vez «qualesquier testamento e testamentos e mandas e codeçildos que fasta aquí yo he fecho e otorgado", documentos de los cuales no tenemos ninguna noticia más.

Catalina fue también nombrada heredera de todos los bienes de su esposo «remanesçientes, asý muebles como raýzes e sermovientes e debdas a my devidas e pertenesçientes en qualquier manera», aunque no se especifican cuáles eran estos, y junto a Beltrán de Mallea, ministril de la reina Isabel y vecino de Valladolid, testamentaria y cabezalera. Además, y en virtud de dicho poder, podría «disponer e ordenar [...] donde my cuerpo sea sepultado e çerca de mis onras e obsequias e descargo de my ányma». Asimismo, Cornalis dispuso la entrega de cinco maravedíes a los monasterios de la Merced y de la Trinidad de Valladolid ${ }^{45}$ y otro maravedí para la «obra del puente».

Actuaron como testigos Fernando, pescador de San Agustín, e Francisco de Guijano e Francisco de Salamanca, carpintero, criado de Juan de Olmedo, Andrés y Alfonso Ganguero, Alfonso de Palencia y Juan Darze, criado del dicho Françisco Guijano, vecinos todos ellos de Valladolid, aunque, curiosamente ninguno relacionado con la actividad musical en la corte ${ }^{46}$.

La ausencia de menciones a hijos en el citado documento y también en el posterior testamento de Catalina Pérez evidencia que Cornalis y Catalina no tuvieron hijos o si los tuvieron ya habían fallecido. Knighton, sin embargo, afirma que Beltrán y Pedro de Mallea, músicos también en la Casa de la reina Isabel, fueron vástagos suyos ${ }^{47}$ y Villanueva Serrano aventura incluso la posibilidad de un tercer hijo llamado Corniels de Mallea, también ministril de la reina ${ }^{48}$.

Catalina Pérez dictó testamento en Valladolid el 11 de diciembre de 1500 ante Juan Martínez, «clérigo, vesino de la noble villa de Valladolid e notario apostólico" y Machín, zapatero, Pero Ganguero y Juan de Palençia, vecinos todos ellos de Valladolid. Por este testamento quedaban anuladas últimas voluntades y el mencionado Beltrán de Mallea y su esposa, llamada también Catalina Pérez, eran nombrados herederos universales y testamentarios de sus bienes, que tampoco son detallados, con la facultad de

en la su corte e chançillería e escrivano público del número de la dicha villa de Valladolid e su tierra e jurediçión».

45 Según Rucquoi, el monasterio de la Trinidad de Valladolid figuraba «... entre los beneficiarios obligados en los testamentos». Sobre ambos centros religiosos véase de A. RucQuor, Valladolid..., vol. I, pp. 185-187.

46 AGS, CySR, Leg. 6, f. 566r-v. Véase 5. Apéndice documental. Doc. 5.

47 T. Knighton, Música y músicos..., pp. 149-150.

48 F. Villanueva Serrano, A la onor..., p. 214. 
aver, cobrar e recabdar todos mys bienes muebles e raýses do quier que los yo aya e tenga e me pertenesçen en qualquier manera et los puedan vender e vendan en almoneda pública e fagan dellos como quisieren e por bien tovieren fasta conplimiento deste dicho my testamento e postrimera voluntad e las obligaçiones, obsequias e logares contenidos ${ }^{49}$

Uno de los aspectos más detallados en el testamento es el relativo al de sus honras fúnebres, probablemente muy similares o idénticas a las celebradas por su marido unos ańos antes. Por el testamento de Catalina, sabemos que Cornalis fue sepultado en la «antigua y aristocrática» iglesia vallisoletana de san Julián ${ }^{50}$, la misma en la que también lo sería años más tarde su mujer, «en la sepultura del dicho mi marido", aunque no hay constancia de que lo hicieran en alguna capilla en concreto.

Siguiendo un ceremonial establecido, la viuda dispuso que la noche antes de su entierro "el cura e clérigos de la dicha iglesia» cantaran la vigilia de difuntos y el mismo día del sepelio hicieran lo propio con la misa de réquiem. En esa jornada se habrían de llevar como ofrenda a dicha iglesia «tres tablas de pan e tres cántaras de vno e tres carneros», señalando que «... si fuere día de pescado que me lleven tres platos dello" y se se rezarían las novenas, además cada domingo por espacio de un año se diría un responso dando para ello a los clérigos de dicha parroquia en aval dos cargas de trigo y cinco reales de plata para que el «cura» de la parroquia rogase por su alma.

El ciclo litúrgico se cerraba con los acostumbrados treintenarios, uno cerrado «e las misas de Santo Amador», consistente en la celebración por parte del sacerdote sin salir de la parroquia de 33 misas que «tenían por objeto el rescate del Purgatorio de las almas de las personas por las que se oficiaba» y la correspondiente quema de candelas en cada una de esas misas, y el otro treintenario abierto, en el que el cura podía salir de la parroquia y dormir en su casa ${ }^{51}$. Dispuso también una misa de cabo de año «e me lleven otro tanto de ofrenda como el día de mi enterramyento e honras».

Catalina no olvidó en sus últimas voluntades a las personas que le sirvieron y rodearon en sus últimos años de vida. A su criada Juana, por ejemplo, le dejó un total de 500 maravedíes "por algo que della tengo» y una saya azul «de las mías»; a Juanita, criada de Beltrán de Mallea, su heredero, 300 maravedíes para ayuda de su boda y al hijo de Sancho Barquero, el antiguo ministril de chirimía de Cornalis, 620 maravedíes «que le son en cargo». A la redención de cautivos destinó un real de plata y a las emparedadas de Valladolid otros cinco maravedíes más «porque rueguen a

49 AGS, CySR, Leg. 6, f. 565r-v. 5. Apéndice Documental. Doc. 6.

${ }^{50}$ Expresión utilizada por Rucquoi. La parroquia había sido fundada en 1095. A. RuQuoI, Valladolid..., vol. I, p. 64 y vol. II, p. 184.

${ }^{51}$ L. Gómez Nieto, Ritos funerarios en el Madrid Medieval. Madrid, Asociación Cultural Almudaina, 1991 y «Las misas por los difuntos. Testamentos madrileños bajomedievales». En la España Medieval, vol. 15 (1992), pp. 353-366. J. BALdó AlCoz, «Las misas post mortem: simbolismos y devociones en torno a la muerte y el más allá en la Navarra bajomedieval». Zainak. Cuadernos de Antropología-Etnografía, vol. 28 (2006), pp. 353-374. 
Dios por my alma.... ${ }^{52}$, también a «... Sant Lázaro e Sant Antón cada dos maravedís» y como ya hizo su marido en 1484 otro maravedí para las obras de «la puente»»3.

Poco sabemos de la trayectoria posterior de Beltrán de Mallea y su esposa Catalina Pérez. Como herederos de Cornalis y Catalina, reclamaron al rey Fernando un total de 1166 maravedíes de los «treze mill maravedís que le salieron ...ynçiertos del año pasado de ochenta de su raçión e quytaçión que tenýa con el dicho ofiçio»" ${ }^{54}$. El monarca accedió a ello y en marzo de 1508 ordenó a Ochoa de Landa, tesorero de los descargos, que se les abonara dicha cantidad ${ }^{55}$, suma que finalmente cobró a finales de ese mismo mes Estíbaliz Zabala en nombre de Beltrán y Catalina ${ }^{56}$.

\section{CONCLUSIÓN}

Como la mayor parte de los músicos procedentes de Alemania, Francia, Flandes o Italia, Cornalis de Alemania contó desde una edad temprana con una sólida formación adquirida en las escuelas de ministriles y cantores que proliferaron a lo largo de la Edad Media por aquellos espacios geográficos.

Concluido ese primer aprendizaje, inició un largo cursus honorum que le llevaría a recalar en la corte de Castilla, por entonces foco de letrados y humanistas y uno de los centros culturales más notables de toda Europa dadas sus sólidas relaciones con los Países Bajos, donde a través de un eficaz entramado de representantes, mercaderes y compradores al servicio de la Corona, Juan II y sus sucesores pudieron hacerse con algunas de las mejores piezas artísticas y con los músicos más destacados de la escuela franco-flamenca.

Admirado por su talento, Cornalis despertó el interés de los demás monarcas hispanos, que no dudaron en contar con sus servicios a precio de oro, Juan II de Castilla primero y más tarde Alfonso V de Aragón, Alfonso V de Portugal, Carlos de Viana, el príncipe Fernando de Aragón y, finalmente, Isabel la Católica le tuvieron entre los miembros de su Casa, señal indiscutible del prestigio que nuestro ministril alcanzó en el desarrollo de sus obligacions profesionales.

52 En la propia iglesia de San Julián había una emparedada a mediados de la década de 1460. Sobre estas beatas en el Valladolid del siglo xv véase A. RuCQUOI, Valladolid..., vol. II, pp. 353-354.

53 AGS, CySR, Leg. 6, f. 565r-v. 5. Apéndice Documental. Doc. 6.

${ }_{54}$ El resto de maravedíes hasta los 13000 , un total 11884 según la cédula real, no llegaron a ser abonados a los herederos porque fueron descontados «... de ruta del ańo de ochenta e quatro que gozó el dicho Corniels de su librança por entero e non ovo de aver los dichos onze mill e ochoçientos e ochenta e quatro maravedís dellos porque fallesçió antes de cunplido el año». La suma de los 1166 maravedies cobrados más los 11884 restantes montan 13050 y no los 13000 mencionados. AGS, CySR, Leg. 6, f. 564v. 5. Apéndice documental. Doc. 7.

55 AGS, CySR, Leg. 6, f. 564r. 5. Apéndice documental. Doc. 7. R. Domínguez Casas, Arte y etiqueta de los Reyes Católicos. Artistas, residencias, jardines y bosques. Madrid, Alpuerto, 1993, p. 161 y 198 nota núm. 979. T. Knighton, Música y músicos..., pp. 149 y 150 y F. DE P. Cañas Gálvez, "La música en la corte de Enrique IV...», p. 269.

56 AGS, CySR, Leg. 6, f. 564v. 5. Apéndice documental. Doc. 8. 
La documentación nos ha permitido saber que sus últimos años los pasó en Valladolid, la villa regia por excelencia y lugar de residencia de muchas de las instituciones más relevantes de la monarquía Trastámara y de buena parte de los oficiales regios que las atendían.

Dueño de un patrimonio no especificado, aunque quizá de alguna importancia si tenemos en cuenta los estipendios que percibió a lo largo de su vida artística, Cornalis falleció en 1484 dejando por heredera universal de todos su bienes «... muebles [...] raýzes e sermovientes...» a su esposa, Catalina Pérez. 


\section{APÉNDICE DOCUMENTAL}

\section{6, noviembre, 8. Valencia}

Alfonso V de Aragón emite un salvoconducto en favor de Castilla, rey de armas, y de (Jean) Colleville, Claus, Perrinet y Jaquet, ministriles de Juan II de Castilla, para que vuelvan a sus tierras.

B.- ACA, Cancillería, Reg. 2.576, f. 152r.

Ministreriorum regis Castelle.

Alfonsus, et cetera, dilectis et fidelibus nostris universis et singulis gubernatoribus, vicariis, iusticiis, baiulis, subbaiulis et aliis officialibus et subditis nostris, nec non custodibus passuum, portuum et rerum prohibitarum in confinibus regnorum et terrarum nostrarum constitutis, et aliis ad quos presentes pervenerint et fuerint presentate, salutem et dileccionem. Cum devoti nostri Castilla, rex armorum, Colavilla, Claus, Parrinetus et Iaquimetus, ministrerii serenissimi regis Castelle, consanguinei nostri carissimi, de nostri licencia et permissu versus partes regni Castelle et alias provincias dirigant de presenti gressus suos, vobis et unicuique vestrum dicimus et mandamus de certa sciencia et expresse, sub nostre gracie et mercedis obtentu, quatenus superius nominatos regem armorum et ministrerios, una cum famulis, servitoribus, equitaturis, auro, argento, peccunia, iocalibus, malis, maletis, bedaciis et aliis quibuscumque rebus et bonis eorum, regna nostra exire et ab hiis recedere, et quo voluerint ire et se conferre, libere permittatis, nec eis aut alicui ipsorum dampnum, violenciam, opressionem, iacturam et molestiam aliquatenus faciatis, ymo pro posse ab omni novitate, dampno et iniuria preservetis, quin pocius recomissos ipsos habeatis. Et si opportuerit, et vos requisiverint, de securo transitu et conductu provideatis et provideri faciatis. Presentibus post tres menses a data huiusmodi in antea continue numerandos minime valituris.

Data Valencie sub nostro sigillo secreto die octava novembris anno a Nativitate Domini MCCCCXXVI.

Rex Alfonsus.

Dominus rex mandavit michi Francisco d'Arinyo.

Probata.

\section{2}

\section{6, noviembre, 10. Valencia}

Alfonso V de Aragón ordena al tesorero Franisco Zarzuela pagar 300 florines de oro de Aragón al rey de armas, Joan de Colonia, Jean Colleville, Jacquinot, Claus y Perrinet, ministriles de chirimia de Juan II de Castilla para los gastos de su viaje.

B.- ACA, Cancillería, Reg. 2.681, f. 75.

Ministreriorum regis Castelle.

Alfonsus, et cetera, dilecto consiliario et thesaurario nostro Francischo Sarçola, militi, legum doctori, salutem et dileccionem. Dicimus et mandamus vobis quatenus de 
peccuniis curie nostre que penes vos sunt vel erunt detis et tradatis Iohanni de Colonya, regi armorum, Iohanni Colavila, Iaquinot, Claus et Perrineto, ministreriis de xaramines illustris regis Castelle, consubrini nostri carissimi, trecentos fflorenos auri de Aragonia quos eisdem, pro strenis et in succurrimento expensarum per ipsos factarum in veniendo de dicto regno Castelle ad curiam nostram predictam, per vos dari volumus et iubemus. Et in solucione eis facienda recuperetis presentem et apocam de soluto.

Data Valencie sub nostri sigillo secreto decima die novembris anno a Nativitate Domini MCCCCXXVI.

Rex Alfonsus.

Dominus rex mandavit michi Francisco d'Arinyo.

Probata.

3

1444, marzo, 11. Castell Nou de Nápoles.

Alfonso Vde Aragón comunica a su tesorero general, Mateo Panadés, que Elaús Alemany, Sacotey de Barcleona, Gilet y Arnau, ministriles de Juan de Castilla, van a Nápoles para servirle con una paga de 400 florines de oro anuales vitalicios a cada uno de ellos. Dispone el monarca que a su llegada a Barcelona les sea dispensado el mejor trato posible y se les adelanten a cada uno de ellos 200 florines de oro de la remuneración del primer año.

B.- ACA, Cancillería, Reg. 2.718, f. $44 v$.

EDIT. H. ANGLÉs, La música..., p. $22^{57}$.

Lo rey d'Aragó e de les Sicilies etc.

Tresorer: Notificamvos com los amats nostres Elaus, alemany, e Jacotey, de Barcelona, e Gilet e Arnau, ministrers del molt alt e molt excelent rey de Castella, nostre molt car e molt amat cosí, se serien acordats ab nos per nostres ministrers, als quals havem donat e consignat quatrecents florins d'or de moneda d'Aragó a casun d'ells, pagadors cascun any de qualsevol peccunies pervenidores e pertanyents a nos o a nostra cort, e açó a vida de cascun d'ells segons veureu es conté en la privisió sobre açó per nos a ells feta.

Per que vos diem a manam que tota hora e quant los dits Elaus, Jacotey e Gilet e Arnau seran aquí dins la ciutat de Barchelona ab ses mullers e bens per habitar dins la dita ciutat, e los sobredits Elaus e Jacotey, Gilet e Anrau volran venir de les parts decá a servirnos, volem que doneu a cascun d'ells docents florins d'or de moneda d'Aragó, comptant los dits docents florins en paga e porrata del primer any e lo restant los sia pagat per lurs tandes...

Dada en lo Castell Nou de Napols a 11 de març del any de la Nativitat de Nostre Senyor MCCCCXXXXIIII.

Rex Alfonsus.

Dirigitur Matheo Panadés, generali thesaurario.

Dominus rex mandavit michi Arnaldo Fonolleda.

57 Copiamos la transcripción aportada por Anglés. 


\section{4, abril, 25}

Cédula de Juan II de Castilla ordenando a Gonzalo de Alba, su repostero de camas, entregar 8.000 maravedies a Luis Garcia de Morales, despensero mayor de las raciones de la Casa del rey, para pagar el tercio primero de las raciones de Pedro de Fox, Cornalis de Alemania, Martín Muñoz del Cardoso y Sancho Barquero, ministriles de chirimía del monarca.

B.- AGS, CySR, leg. 42, f. $1 \mathrm{~m}$.

EDIT. F. de P. Cañas Gálvez, «El despensero...», Doc. 30, p. 176.

Luys Garçía de Morales, despensero mayor de nuestro señor el rey de las raçiones del dicho señor rey de la su casa.

Mostró vna çédula del rey nuestro señor firmada de su nonbre fecha en esta guisa:

El rey.

Gonçalo de Alva, mi repostero de camas, yo vos mando que de qualesquier maravedís que por mi mandado avedes resçebido o rrescebiéredes en qualquier manera para los tener en la mi cámara dedes e paguedes luego a Luis Garçía de Morales, mi despensero mayor de las raçiones de la mi casa, ocho mill maravedís que es mi merçed que los resçiba de vos para los dar e pagar a Pedro de Fox e Cornalis de Alemaña e a Martýn Muñoz del Cardoso e a Sancho Barquero, mis ministriles de cheremías, a cada vno de ellos dos mill maravedís para en cuenta de sus raçiones que de mi tyenen e han de aver del terçio primero de este año de la fecha de esta mi çédula e dadgelos e pagadgelos luego e tomad su carta de pago con la qual e con con esta mi çédula mando a los mis contadores mayores de las mis cuentas que vos resçiban en cuenta los dichos ocho mill maravedís e non fagades ende al.

Fecho veynte e çinco días de abril año del nasçimiento del nuestro señor Ihesu Christo de mill e quatroçientos e çinqüenta e quatro años.

Yo el rey.

Por mandado del rey, Pero Ferrándes.

E en las espaldas de la dicha çédula estaua escripto esto que se sygue: Gonçalo de Alua, repostero de camas del rey nuestro señor, de esta otra parte contenydo ved esta çédula del dicho seńor rrey e conplidla en todo e por todo segund se en ella contyene e su altesa por ella vos enbia mandar.

(Al margen, a la izquierda: año de IUCCCCLIIII años. Cámara. El despensero Luys Garçía).

(Al margen, a la derecha: VIIIU maravedís).

\section{5}

\section{4, junio, 29. Valladolid.}

Carta por la que Corniels de Alemania, ministril de la reina Isabel, otorga poder a su esposa Catalina Pérez para que en su nombre pudiese otorgar testamento. Nombra también a su mujer heredera universal y, junto a Beltrán de Mallea, ministril de la riena, su testamentaría.

$$
\text { A.- AGS, CySR, Leg. 6, f. 566r-v. }
$$


Yn dey nómine, amén.

Sepan quantos esta carta vieren como yo, Corniels de Alemania, menestril de la reyna, nuestra señora, vezino que soy de la noble villa de Valladolid e estando sano de mi cuerpo e en mi seso e entendimiento natural tal qual nuestro señor Dios plogó de me dar e creyendo firmemente en la Santa Trenidad, Padre e Fijo e Espíritu Santo, que son tres personas e un sólo Dios verdadero que vive e reyna por syenpre syn fin e temiéndome la muerte, de la qual todo fiel christiano se debe temer, e por algunas cabsas e razones que a ello me mueven conosco e otorgo por esta carta que do e otorgo my poder conplido bastante llenero asý como lo yo he e tengo e segund que mejor e más conplidamente lo puedo e devo dar e otorgar de derecho a vos, Catalina Pérez, muy muger, que presente estades, para que por my e en mi nonbre podades fazer e ordenar e fagades e ordenedes my testamento e postrimera voluntad e para que podades disponer e ordenar e, quando a nuestro señor plugiere de me llevar desta presente vida, donde my cupero sea sepultado e çerca de mis onras e obsequias e descargo de my ányma, conosco que lo remito e dexo a vos, la dicha Catalina Pérez, my muger, para que vos lo fagades e descarguedes de my ányma e conçiençia como vos quisiéredes e por bien toviéredes.

E mando que den a los monesterios de la Trenydad e de la Merçed desta dicha villa de Valladolid para ayuda a redemyr de sacar christianos cativos de tierra de moros a cada monesterio çinco maravedís, e para la obra de la puente, un maravedí.

E para conplir e pagar lo que dicho es en el testamento e mandas que vos, la dicha Catalina Pérez, my muger, por virtud desta carta de poder en mi nonbre fiziéredes o ordenáredes e mandáredes dexo por mys testamentarios e cabeçaleros a vos, la dicha Catalina Pérez, my muger, e a Beltrán de Mallea, ministril de la dicha seńora reyna e vezino de la dicha de Valladolid, amos a dos juntamente, e vos do e otorgo poder conplido con todas sus ynçidençias e dependençias e emergençias e anexidades e conexidades para entrar e tomar mys bienes muebles e raýzes e sermovyentes e conplir e pagar lo que dicho es e las mandas que vos, al dicha Catalina Pérez, my muger, por virtud del testamento que por virtud deste poder en my nonbre fiziéredes e ordenáredes conplido e pagado el tal testamento que asý vos, al dicha Catalina Pérez, my muger, fiziéredes e ordenáredes e otorgáredes e las mandas e descargo de mi ányma que por virtud dél fiziéredes e otorgárdes a todo lo que en el dicho testamento fuere contenido.

Conosco e otorgo por esta carta que dexo por my heredera en todos los otros mys bienes remanesçientes, asý muebles como raýzes e sermovientes e debdas a my devidas e pertenesçientes en qualquier manera a vos, la dicha Catalina Pérez, my muger, e vos apodero en todos los dichos my bienes e vos do poder conplido para que los podades entrar e tomar e resçebir e recabdar e dar e otorgar carta o cartas de pago dellos, las quales valan e sean firmes e bastantes bien asy como si yo mesmo las diese e otorgase e reconosçiese.

E do por ningunos e de ningund valor e efeto todos e qualesquier testamento e testamentos e mandas e codeçildos que fasta aquí yo he fecho e otrogado, los quales e cada uno dellos mando que non valan nin fagan fe en juyzio ni dél, salvo el testamento e mandas que vos, la dicha Catalina Pérez, my muger, fiziéredes e ordenáredes e otorgáredes en my nonbre como dicho es, el qual quyero e mando que valga asý como mi testamento e sy valiere por testamento sy non mando que valga por codeçildo e sy valiere por codeçildo sy non mando que valga asý como my postrimera voluntad o en la mejor manera a forma que puede e debe valer de derecho. 
E porque esto sea firme e non venga en dubda esta carta de poder, otorgué ante Juan Álvares de Valladolid, escrivano de cámara del rey e reyna, nuestros seńores, e su notario público en la su corte e en todos los sus reynos e señoríos e escrivano de la su abdiençia e de la provinçia de Castilla en la su corte e chançillería e escrivano público del número de la dicha villa de Valladolid e su tierra e jurediçión, al qual rogué e pedí que la escriviese o fiziese escrevir e la sygnase de su sygno e a los presentes que fuesen dello testigos.

Desto son testigos que fueron presentes llamados e rogados para esto que dicho es: Fernando, pescador de San Agostín, e Françisco de Guijano e Françisco de Salamanca, carpentero, criado de Juan de Olmedo, e Andrés Ganguero e Alfonso Ganguero e Alfonso de Palençia e Juan Darze, criado del dicho Françisco Guijano, vezinos de la dicha villa de Valladolid.

Fecha e otorgada fue esta carta de poder en la noble villa de Valladolid a veynte e nueve días del mes de junio año del nasçimiento del nuestro señor Ihesu Christo de mill e quatroçientos e ochenta e quatro años.

Va entre renglones o dis: mes e o dis: fues esta carta.

Yo, el dicho Juan Álvarez de Valladolid, escrivano e notario público sobredicho, fuy presente a todo lo que dicho es en uno con los dichos testigos e a ruego e otorgamyento del dicho Cornieles de Alemania, menestril, esta carta de poder en la manera que dicha es fise escrevir e fise en ella este mío signo en testimonio de verdad.

Juan Álvares (signo).

\section{6}

\section{0, diciembre, 11. Valladolid.}

Catalina Pérez, viuda de Corniels de Alemania, difunto, otorga testamento dejando por sus herederos universales a Beltrán de Mallea, ministril de la corte, y a la esposa de este, llamada también Catalina Pérez.

A.- AGS, CySR, Leg. 6, f. 565r-v.

In dei nómine, amén.

Sepan quantos este público instrumento de testamento e postrimera voluntad vieren, como yo, Catalina Péres, muger de Cornyelis, ministril de los reyes, nuestros señores, que santa gloria aya, vesina de la noble villa de Valladolid, estando enferma del my cuerpo e sana del mi buen entendimyento tal cual plugo al mi señor Dios de me lo querer dar, creyendo firmemente en Dios Padre, Hijo e Spíritu Santo, tres personas e un solo Dios verdadero e todo lo que nuestra Santa Madre Iglesia tyene e cree e enseńa e temiendo la muerte que es natural a todos los bevientes e del día i hora della todos somos inçiertos e non sabidores, por lo qual nos conviene estar aparejados para quando a nuestro señor plogyere de nos llamar que le podamos dar buena cuenta de lo que nos fuere demandado, otorgo e conosco que fago e ordeno my testamento e postrimera voluntad a serviçio de Dios e de nuestra seńora la Virgen María, su madre, e loor e alabança suya e de toda la corte çelestial para descargo de mi conçiençia e satisfaçión de mis culpas e errores en la siguyente manera:

Primeramente, mando mi alma al my señor Ihesu Christo que la crió e conpró e redimió por su preçiosa sangre, e el cuerpo a la tierra de donde fue formado, e mando que 
quando al mi señor Dios ploguyere de me levar desta presente vida quel my cuerpo fuere sepultado dentro de la iglesia de Sant Julián, en la sepultura del dicho mi marido.

Otrosý, mando quel cura e clérigos de la dicha iglesia me honren e entierren e me digan vegilias ante noche e otro día misa de Requiem cantados e les den sus derechos acostunbrados.

Otrosý, mando que me lleven ofrenda a la dicha eglesia el día de mi enterramyento o honras tres tablas de pan e tres cántaras de vino e tres carneros, e y fuere día de pescado que me lleven tres platos dello segund costunbre desta dicha villa.

Otrosý, que me fagan en la dicha yglesia mys novenas segund costunbre desta dicha villa.

Otrosý, mando que den a los dichos clérigos de Sant Julián por en aval dos cargas de trigo e ellos sean obligados a desir my responso cada domingo por vn ańo entero segund costunbre desta dicha villa.

Otrosý, mando que me digan en la dicha yglesia un treyntenario cerrado e las misas de Santo Amador e sean pagados segund costunbre desta dicha villa.

Otrosý, mando que me digan en la dicha yglesia un treyntenario abierto e den para él segund costunbre desta dicha villa.

Otrosý, mando que den al cura de San Julián çinco reales de plata para que ruegue a Dios por my alma.

Otrosý, mando que me fagan cabo de año e me lleven otro tanto de ofrenda como el día de mi enterramyento e honras.

Otrosý, a my criada Juana quinientos maravedís por algo que della tengo e más le mando una saya azul de las mías.

Otrosý, mando a Juanita, criada de Beltrán de Mallea, tresçientos maravedís para ayuda a su casamyento.

Otrosý, mando que den al fijo de Sancho Barquero seysçientos et veynte maravedís que le son en cargo.

Otrosý, mando por la redenpçión de captivos un real de plata e a las casas de las enparedadas desta dicha villa cada çinco maravedís porque rueguen a Dios por my alma, e a Sant Lázaro e Sant Antón cada dos maravedís e a la puente un maravedí.

Et para conplir e pagar e executar este my testamento e postrimera voluntad con todas las mandas e obsequias e ¿̇seguros? en él contenidos dexo por mys testamentarios al dicho Beltrán de Mallea e a Catalina Péres, su muger, a los quales doy e otorgo todo mi poder conplido segund que lo yo he e tengo e segund que mejor e más conplidamente lo puedo e devo dar e otorgar de derecho para que puedan aver, cobrar e recabdar todos mys bienes muebles e raýses do quier que lo yo aya e tenga e me pertenesçen en qualquier manera et los puedan vender e vendan en almoneda pública e fagan dellos como quisieren e por bien tovieren fasta conplimiento deste dicho my testamento e postrimera voluntad e las obligaçiones, obsequias e logares contenidos.

E cunplido e pagado el dicho mi testamento con todo lo en él contenido en los bienes remanesçientes dexo por mis unyversales herederos a los dichos Beltrán e Catalina Pérez, su muger, los quales quiero e mando que los ayan e hereden e non otra persona alguna e anullo e doy por ninguno todos e qualesquier testamento o testamentos, codesildo o codesildos que y fasta quí aya fecho, asý por palabra como por escripto que no valga nin faga fee salvo este que yo agora fago, el qual quiero e mando que valga por my testamento 
e postrimera voluntad o en aquella forma e manera que mejor e más conplidamente pueda e debe valer de derecho.

Et porque esto sea fyrme e no venga en dubda firmé esta carta de testamento e postrimera voluntad antel notario e testigos de yuso escriptos, al qual rogué que la escriviese e fisiese escrevir e la sygnase con su sygno e a los presentes que dello sean testigos.

Desto fueron testigos que fueron presentes llamados e rogados a lo que dicho es: Machín, çapatero, e Pero Ganguero e Juan de Palençia, vezinos de la dicha villa.

E yo, Iohan Martínes, clérigo, vesino de la noble villa de Valladolid, e notario apostólico, fui presente en uno con los dichos testigos a todo lo que dicho es, e a ruego e otorgamiento de la dicha Catalina Péres este público instrumento de testamento e postrimera voluntad escreví, el qual fue fecho en la dicha villa de Valladolid a honse días del mes de disienbre año de mill e quinientos años.

Por ende, fise aquí este mi signo e rública en testimonio de verdad, rogado e requerido.

Iohan Martínes, apostolicus notario (signo).

\section{7}

\section{8, marzo, 17. Burgos.}

Cédula de Fernando el Católico a Ochoa de Landa, su tesorero de los descargos, ordenándole que pagase a los herederos de Cornalis de Alemania, ya difunto, ministril alto de la reina Isabel, los 1.166 maravedies que se le debian de su ración y quitación del año 1480.

A.- AGS, CySR, Leg. 6, f. 564 r.

El rey.

Ochoa de Landa, thesorero de los descargos, yo vos mando que de qualesquier maravedís de vuestro cargo dedes y paguedes a los herederos de Corniels de Alemańa, defunto, menestril alto que fue de la señora reyna, my muger, que aya santa gloria, o a quyen su poder oviere, mill e çient e sesenta e seys maravedís de los treze mill maravedís que le salieron ynçiertos del año pasado de ochenta de su raçión e quytaçión que tenýa con el dicho ofiçio, a razón de treynta mill maravedíes por año, et los otros onze mill e ochoçientos e ochenta e quatro maravedís a cunplimyento de los dichos treze mill maravedíes que ovo de aver del dicho año se le descuentan de ruta del año de ochenta e quatro que gozó el dicho Corniels de su librança por entero e non ovo de aver los dichos onze mill e ochoçientos e ochenta e quatro maravedís dellos porque fallesçió antes de cunplido el año.

E dádgelos e pagádgelos en dineros contados e tomad su carta de pago, o de quien el dicho su poder ouiere, con la qual e con esta çédula tomando la razón della el secretario Juan López mando que vos sean resçebidos en cuenta los dichos maravedís, e non fagades ende al.

Fecha en Burgos a diez e siete días del mes de março de mill e quinientos e ocho años. Yo el rey (rúbrica).

Por mandado de su alteza, Juan Lópes (rúbrica).

A Ochoa de Landa que pague a los herederos de Corniels de Alemaña, menestril alto de su alteça, IUCLXVI maravedís que se salieron ynçiertos de la librança de su ración e quitaçión del año de LXXX. 


\section{8, marzo, 25. Burgos}

Estíbaliz de Zabala, en nombre de Beltrán Mallea y Catalinz Pérez, herederos de Corniels de Alemania, reconoce haber recibido de Ochoa de Landa, tesorero de los descargos, los 1.166 maravedies que se le debian a Corniels correspondientes al año 1480.

\section{A.- AGS, CySR, Leg. 6, f. $564 \mathrm{v}$.}

Conosco yo, Estívaliz de Çabala, que resçebí de Ochoa de Landa, thesorero de los descargos, los mill e çiento e sesenta e seys maravedís desta otra parte contados por Beltrán de Mallea e Catalina Péres, su muger, herederos de Corniels de Alemańa, por virtud del poder que de los dichos herederos tengo, el qual poder y los testamentarios de Corniels e su muger quedan en poder del dicho thesorero. Et porques verdad que los resçebí en dineros contados firmé aquí de my nonbre.

Fecho en Burgos a veynte e quatro días de março de mill e quinientos e ocho años. Es la quantía mill e çiento e sesenta e seys maravedís.

Estíbalis de Çabala (rúbrica).

Asentada. 


\section{BIBLIOGRAFÍA}

Andrés, Ramón, Diccionario de instrumentos musicales. Desde la Antigüedad hasta J.S. Bach. Barcelona, Península, 2001.

ANGlés, Higinio, «Cantors und Ministrers in den Diensten der Könige von Katalonien-Aragonien im 14. Jahrhundert». Berich über den Musikwinssenschaftlichen Kongress in Basel 1924, Leipzig, 1925, pp. 55-66.

ANGlés, Higinio, «El músci Jacomí al servei de Joan I i Martí I durante els anus 1372-1404», en A.M. PAGÈs (ed.), Homenatge a Antoní Rubió i Lluch. Miscellània d'estudis literaris, històrics i linguistics, Barcelona, 1935, pp. 613-625.

Anglés, Higinio, «Els cantors i organistes franco-flamencs i alemanys a Catalunya els segles XIVXVI», en Scripta Musicologica, cura et studio Iosephi López Calo, II, Roma, 1975, pp. 735-751.

Anglés, Higinio, «La música en la corte real de Aragón y de Nápoles durante el reinado de Alfonso V el Magnánimo (1416-1458)». Cuadernos de Trabajos de la Escuela Española de Historia y Arqueología en Roma, vol. 11 (1961), pp. 83-141.

Anglés, Higinio, Historia de la música medieval en Navarra. Pamplona, Diputación Foral de Navarra, 1970.

Anglés, Higinio, La música en la Corte de los Reyes Católicos. I. Polifonía religiosa. Barcelona, CSIC, 1960.

Atlas, Allan W., Music at the Aragonese Court of Naples. Cambridge, Cambridge University Press, 1995.

BAldó Alcoz, Julia, «Las misas post mortem: simbolismos y devociones en torno a la muerte y el más allá en la Navarra bajomedieval». Zainak. Cuadernos de Antropología-Etnografía, vol. 28 (2006), pp. 353-374.

Cañas Gálvez, Francisco de Paula, «La música en la Corte de Juan II de Castilla (1406-1454). Nuevas fuentes para su estudio». Revista de Musicología, vol. xxıII, núm. 2 (2000), pp. 380 y 393-394.

Cañas Gálvez, Francisco de Paula, «La música en la corte de Enrique IV de Castilla (1454-1474). Una aproximación institucional y prosopográfica». Revista de Musicología, vol. xxıx, núm. 1 (2006), p. 269.

Cañas Gálvez, Francisco de Paula, «Música, poder y Monarquía en la Castilla Trastámara (13691474). Nuevas perspectivas de análisis». Revista de Musicología, vol. xxxıI, núm. 1 (2009), pp. 359-378.

Cañas Gálvez, Francisco de Paula, «La itinerancia de la corte de Castilla durante la primera mitad del siglo xv: el eje Burgos-Toledo, escenario burocrático-administrativo y político de la Monarquía en tiempos de Juan II». L'Itinérance des cours (fin XII ${ }^{\mathrm{e}}$. siècle milieu XV ${ }^{\mathrm{e}}$. siècle): un modèle ibérique?, e-Spania, núm. 8 (2009), https://journals.openedition.org/e-spania/18545.

Cañas Gálvez, Francisco de Paula, «La cámara de Juan II: vida privada, ceremonia y lujo en la corte de Castilla a mediados del siglo xv», en Andrés Gambra Gutiérrez y Félix Labrador Arroyo (eds.), Evolución y estructura de la Casa Real de Castilla, vol. 1, Madrid, Ediciones Polifemo, 2010, pp. 152-153.

Cañas Gálvez, Francisco de Paula, «La Casa de Juan I de Castilla: aspectos domésticos y ámbitos privados de la realeza castellana a finales del siglo XIv (ca. 1370-1390)». En la España Medieval, vol. 34 (2011), pp. 158-161. 
Cañas Gálvez, Francisco de Paula, «El despensero mayor de las raciones de la Casa del rey. Estudio institucional y documentos de un oficio curial en la Castilla Trastámara (1380-1465)». Cuadernos de Historia del Derecho, vol. 22 (2015), pp. 117-185.

Cañas Gálvez, Francisco de Paula, La cámara real de Juan II de Castilla. Cargos, descargos, cuentas e inventarios (1428-1454). Madrid, Ediciones de La Ergástula, 2016.

Cañas Gálvez, Francisco de Paula, «Juan II de Castilla y el tríptico de Miraflores: marco espiritual, proyección política y propaganda regia en torno a una donación real (1445)», en Lorne Campbell y José Juan Pérez Preciado (eds.), Rogier van der Weyden y España. Actas del Congreso Internacional, Madrid, Museo del Prado, 2016, pp. 20-29.

Cañas Gálvez, Francisco de Paula, «La Casa del infante Fernando de Castilla: corte, poder y representación político-institucional en el ocaso del Medievo (1385-1408)». Boletín de la Real Academia de la Historia, tomo ccxxiII, cuaderno I (2016), pp. 61-70.

Carrillo de Huete, Pedro, Crónica del halconero de Juan II. Edición y estudio de Juan de Mata Carriazo, Madrid, Espasa-Calpe, 1946.

Chacón, Gonzalo, Crónica de Don Álvaro de Luna, condestable de Castilla, maestre de Santiago. Edición y estudio de J. de Mata Carriazo, Madrid, Espasa-Calpe, 1940.

D’Agostino, Gianluca, «La musica, la cappelle e il cerimoniale alla corte aragonese di Napoli'», en Cappelle musicali fra corte, stato e chiesa nell'Italia del rinascimento. Atti del convegno internazionale Camaiore, 21-23 ottobre 2005, Florencia, Olschki, 2007, pp. 153-180.

Descalzo, Andrés, «Músicos en la corte de Pedro IV el Ceremonioso (1336-1387)». Revista de Musicología, vol. XIII, núm. 1, (1990), pp. 401-419.

Domínguez Casas, Rafael, Arte y etiqueta de los Reyes Católicos. Artistas, residencias, jardines y bosques. Madrid, Alpuerto, 1993.

Fernández de Córdova Miralles, Álvaro, «L'impact de la Bourgogne sur la cour castillane des Trastamare», en W. Paravicini (dir.), La cour de Bourgogne et l'Europe. Le rayonnement et les limites d'un modèle culturel, Ostfildern, Jan Thorbecke Verlag, 2013, pp. 593-630.

Fiala, David, Le mécénat musical des ducs de Bourgogne et des princes de la Maison de Habsbourg (1467-1506). Etude documentaire et prosopographique. Tesis doctoral inédita, Université François Rabelais, Tours, 2002.

Gimeno, Francisco M., Daniel Gozalbo y Josep Trenchs, Ordinaçions de la Casa y Cort de Pere el Cerimoniós. Valencia, Universidad de Valencia, 2009.

Gómez Muntané, María del Carmen, La música en la Casa Real catalano-aragonesa, 1336-1442. Vol. 1, Barcelona, Antoni Bosch, editor, 1977.

Gómez Muntané, María del Carmen, «Sobre el papel de España en la música europea del siglo XIV y primer tercio del siglo XV», en J. López-Calo, I. Fernández de la Cuesta, E. Casares RoDicio (coords.), España en la música de occidente: actas del congreso internacional celebrado en Salamanca, 29 de octubre-5 de noviembre de 1985, vol. 1, 1987, pp. 45-48.

Gómez Muntané, María del Carmen, "La música laica en el reino de Castilla en tiempos del Condestable Don Miguel Lucas de Iranzo (1458-1473)». Revista de Musicología, vol. xIX, núms. 1-2 (1986), pp. 25-45.

Gómez Muntané, María del Carmen, «Minstrel schools in the late Middle Ages». Early Music, vol. XVIII (1990), pp. 212-216.

Gómez Muntané, María del Carmen, La música medieval en España. Edition Reichenberger, Kassel, 2001. 
Gómez Muntané, María del Carmen, «Las escuelas de ministriles a finales de la Edad Media». Goldberg, núm. 41 (2006), pp. 59-67.

Gómez Muntané, María del Carmen, «La música en la corte de Alfonso V el Magnánimo», en Eduard Mira y An Delva (eds.), A la búsqueda del Toisón de Oro: la Europa de los principes, la Europa de las ciudades: Almudin, Museo de la Ciudad, 23 de marzo al 30 de junio de 2007, Valencia, Generalitat Valenciana, 2007, vol. 1, pp. 201-211

Gómez Muntané, María del Carmen, «Música y corte a fines del Medioevo: el episodio del Sur», en Historia de la música en España e Hispanoamérica, vol. 1 (De los orígenes hasta c. 1470), Madrid, Fondo de Cultura Económica, 2009, pp. 238-320.

Gómez Nieto, Leonor, Ritos funerarios en el Madrid Medieval. Madrid, Asociación Cultural Almudaina, 1991.

Gómez Nieto, Leonor, «Las misas por los difuntos. Testamentos madrileños bajomedievales». En la España Medieval, vol. 15 (1992), pp. 353-366.

González Marrero, María del Cristo, La Casa de Isabel la Católica. Espacios domésticas y vida cotidiana. Ávila, Diputación Provincial de Ávila; Institución Gran Duque de Alba, 2004.

Knighton, Tess, Música y músicos en la corte de Fernando el Católico, 1474-1516. Zaragoza, Institución Fernando el Católico, 2002.

Knighton, Tess, «Instruments, instrumental music and instrumentalists: Traditions and transitions», en The Companion to Music in the Age of the Catholic Monarchs, Boston, Leiden, Brill, 2017, pp. 97-144.

Knighton, Tess, The Companion to Music in the Age of the Catholic Monarchs. Boston, Leiden, Brill, 2017.

MARIX, Jeanne, Histoire de la musique et des musiciens de la cour de Bourgogne sous le règne de Philippe le Bon (1420-1467). Estrasburgo, Hetiz \& Co, 1939.

Narbona Cárceles, María, "La actividad musical en la corte de Carlos III el Noble de Navarra, 1387-1425». Príncipe de Viana, año 67, núm. 238 (2006), pp. 313-334.

Paravicini, Werner, «The Court of the Dukes of Burgundy. A Model for Europe?», en Ronald G. Asch y Adolf M. Brrke (eds.), Princes, Patronage, and the Nobility. The Court at the Beginning of the Modern Age. c. 1450-1650, Oxford, Oxford University Press for the German Historical Institute Londres, 1991, pp. 69-102.

Rucquor, Adeline, Valladolid en la Edad Media, vol. 2. Valladolid, Junta de Castilla y León, 1997.

Sebastián de Covarrubias orozco, Tesoro de la lengua castellana o española. Madrid, Luis Sánchez, 1611. http://www.cervantesvirtual.com/obra/tesoro-de-la-lengua-castellana-o-espanola-0/.

Udina Martorell, Federico, Guía histórica y descriptiva del Archivo de la Corona de Aragón. Madrid, Dirección General de Bellas Artes y Archivos, 1986.

Valdeón Baruque, Julio, Los Trastámara: el triunfo de una dinastía bastarda. Madrid, Temas de Hoy, 2001.

Valdeón Baruque, Julio, La dinastía de los Trastámara. Madrid, Ediciones El Viso, 2006.

Villanueva Serrano, Francesc, A la onor e mostrar stado. La música en la corte de Juan II de Aragón. Madrid, Sociedad Española de Musicología, 2017.

Wright, Craig M., Music at the Court of Burgundy, 1364-1419. A Documentary History. Musicological Studies, xxviII, Henryville, PA, Institute of Mediaeval Music, 1979. 